\title{
Sauchinone Suppresses Pro-inflammatory Mediators by Inducing Heme Oxygenase-1 in RAW264.7 Macrophages
}

\author{
Bin Li, ${ }^{a, \#}$ Dong-Sung Lee, ${ }^{a, \#}$ Hyun-Gyu Chol, ${ }^{a}$ Kyoung-Su KIm,,${ }^{a}$ Dae-Gil Kang, ${ }^{c, d}$ Ho-Sub LeE,${ }^{c, d}$ \\ Gil-Saeng JEONG, ${ }^{*, b}$ and Youn-Chul KIM ${ }^{*, a}$ \\ ${ }^{a}$ Standardized Material Bank for New Botanical Drugs, College of Pharmacy, Wonkwang University; ${ }^{c}$ College of Oriental \\ Medicine and Professional Graduate School of Oriental Medicine, Wonkwang University; ${ }^{d}$ Hanbang Body-fluid Research \\ Center, Wonkwang University; Iksan 570-749, Republic of Korea: and ${ }^{b}$ College of Pharmacy, Keimyung University; Dae- \\ gu 704-701, Republic of Korea. \\ Received April 7, 2011; accepted July 8, 2011; published online July 14, 2011
}

Sauchinone, a biologically active lignan isolated from the roots of Saururus chinensis (Lour.) BAILL. (Saururaceae), is reported to exert a variety of biological activities, such as hepatoprotective, anti-inflammatory actions and inhibitory effects on bone resorption. In this study, we investigated the effect of sauchinone in suppressing cyclooxygenase-2 (COX-2) and inducible nitric oxide synthase (iNOS) expression, leading to a reduction in COX2-derived prostaglandin $\mathrm{E}_{2}\left(\mathrm{PGE}_{2}\right)$ and iNOS-derived nitric oxide (NO) production in lipopolysaccharide (LPS) stimulated RAW264.7 macrophages. Present study also demonstrates the effects of sauchinone in inducing heme oxygenase-1 (HO-1) expression and an increase in heme oxygenase (HO) activity in RAW264.7 macrophages. The effects of sauchinone on LPS-induced $\mathrm{PGE}_{2}$, NO, tumor necrosis factor- $\alpha$ (TNF- $\alpha$ ) and interlukine-1 $\beta$ (IL-1 $\beta$ ) production were partially reversed by the HO-1 inhibitor Tin protoporphyrin was also seen in this study. In addition, we found that treatment with extracellular signal-regulated kinase (ERK) inhibitor (PD98059) reduced sauchinone-induced HO-1 expression. Sauchinone also increased ERK phosphorylation. These results suggest that sauchinone inhibits pro-inflammatory mediators through expression of anti-inflammatory HO-1 via ERK pathway.

Key words sauchinone; heme oxygenase-1; pro-inflammatory mediator; RAW264.7 macrophage; extracellular signal-regulated kinase phosphorylation

Heme oxygenase-1 (HO-1) is a rate-limiting enzyme in heme catabolism responsible for catalyzing the split of free heme into carbon monoxide (CO), free iron and biliverdin/bilirubin. ${ }^{1)}$ Recent studies have shown that HO-1 has proven involvment in the resolution of inflammatory responses. ${ }^{2)} \mathrm{HO}-1$ and its enzymatic by-products are the critical regulators of inflammation predominantly targeted against macrophages. ${ }^{3)}$ Studies have shown that the anti-inflammatory action of HO-1 is mediated by inhibition of the production of pro-inflammatory cytokines and chemokines such as tumor necrosis factor- $\alpha$ (TNF- $\alpha$ ), interleukin- $1 \beta$ (IL-1 $\beta$ ) and interleukin (IL)-6 in activated macrophages. ${ }^{4,5)}$ Studies indicate that HO-1 and its product carbon monoxide (CO) can suppress the expression of the pro-inflammatory cyclooxygenase-2 (COX-2) and inducible nitric oxide synthase (iNOS), thereby reducing COX-2-drived prostaglandin $\mathrm{E}_{2}\left(\mathrm{PGE}_{2}\right)$ and iNOS-derived nitric oxide $(\mathrm{NO})$ production. ${ }^{6,7)}$ Mitogen-activated protein kinases (MAPKs) is one of the most common signaling pathways that serve to coordinate the cellular response to a variety of extracellular stimuli. MAPKs have an important role in cellular processes, such as proliferation, stress responses, apoptosis and immune defense. ${ }^{8)}$ The MAPK activation also modulates several gene and protein expression including the activation of HO- $1 .{ }^{9,10)}$

Saururus chinensis (Lour.) BAILL. (Saururaceae) has been traditionally used for the treatment of various diseases such as beriberi, pneumonia, urinary disorders, jaundice and gonorrhea. In Korea this plant is a known folk medicine, used for the treatment of edema. ${ }^{11)}$ Sauchinone, a biologically active lignan isolated from the roots of $S$. chinensis, exibits various pharmacological activities, including hepatoprotective, antiinflammatory, cytoprotective and immunosuppressive effects. ${ }^{12-16)}$ Moreover, several published studies demonstrate the inhibitory effect of sauchinone on LPS-induced expression of iNOS, iNOS-derived nitric oxide, TNF- $\alpha$ and COX-2 in murine macrophages. ${ }^{12,17)}$ As a part of our ongoing research to identify phytochemicals isolated from natural sources that can induce HO-1 in vitro, ${ }^{18,19)}$ sauchinone was shown significantly induce the levels of HO-1 in RAW264.7 macrophages. In this study, we demonstrate that the effects of sauchinone on lipopolyscharride (LPS)-induced $\mathrm{PGE}_{2}, \mathrm{NO}$, TNF- $\alpha$ and IL- $1 \beta$ production were partially reversed by the HO-1 inhibitor tin protoporphyrin. We further provided evidence to support the role of HO-1 in mediation of the antiinflammatory effects of sauchinone. Further this study provided evidence that HO-1 is a critical mechanism by which sauchinone exerts anti-inflammatory effects.

\section{MATERIALS AND METHODS}

Chemicals and Reagents Dulbecco's modified Eagle's medium (DMEM), fetal bovine serum (FBS), and other tissue culture reagents were purchased from Gibco BRL Co. (Grand, NY, U.S.A.) Tin protoporphyrin IX (SnPP IX), an inhibitor of $\mathrm{HO}$ activity, was obtained from Porphyrin Products (Logan, UT, U.S.A.). All other chemicals were obtained from Sigma Chemical Co. (St. Louis, MO, U.S.A.). Sauchinone $(>95 \%)$ was deposited at the Standardized Material Bank for New Botanical Drugs (No. NNMBP014), Wonkwang University (Republic of Korea). Sauchinone was isolated from $S$. chinensis using a method described by Jeong et al. ${ }^{20)}$ Primary antibodies, including HO-1, COX-2, iNOS and secondary antibodies were purchased from Santa Cruz Biotechnology (Heidelberg, Germany). Enzyme-linked immunosorbent 
assay (ELISA) kits for $\mathrm{PGE}_{2}$, TNF- $\alpha$ and IL- $1 \beta$ were from R\&D Systems, Inc. (Minneapolis, MN, U.S.A.).

Cell Culture and Viability Assay RAW264.7 macrophages were maintained at $5 \times 10^{5}$ cells per $1 \mathrm{ml}$ in DMEM medium supplemented with $10 \%$ heat-inactivated FBS, penicillin $\mathrm{G}(100 \mathrm{unit} / \mathrm{ml})$, streptomycin $(100 \mathrm{mg} / \mathrm{ml})$, and L-glutamine (2 mM) and was incubated at $37^{\circ} \mathrm{C}$ in a humidified atmosphere containing $5 \% \mathrm{CO}_{2}$ and $95 \%$ air. For determination of cell viability, $50 \mathrm{mg} / \mathrm{ml}$ of 3-[4,5-dimethylthiazol-2-yl]-2,5-diphenyltetrazolium bromide (MTT) was added to $1 \mathrm{ml}$ of cell suspension $\left(1 \times 10^{5}\right.$ cells per $1 \mathrm{ml}$ in 96-well plates) for $4 \mathrm{~h}$, and the formazan formed was dissolved in acidic 2-propanol; optical density was measured at $590 \mathrm{~nm}$.

Nitrite Assay The nitrite concentration in the medium was measured as an indicator of NO production as per Griess reaction. One hundred microliters of each supernatant was mixed with the same volume of Griess reagent; absorbance of the mixture at $525 \mathrm{~nm}$ was determined with an ELISA plate reader.

PGE $_{2}$ Assay Macrophages were cultured in 24-well plates, pre-incubated for $12 \mathrm{~h}$ with different concentrations of sauchinone and then stimulated for $18 \mathrm{~h}$ with LPS. One hundred microliters of supernatant of culture medium was collected for the determination of $\mathrm{PGE}_{2}$ concentration using the ELISA kit (R\&D Systems, Minneapolis, MN, U.S.A.).

TNF- $\boldsymbol{\alpha}$ and IL-1 $\boldsymbol{\beta}$ Assay Macrophages were cultured in 24-well plates, pre-incubated for $12 \mathrm{~h}$ with various concentrations of sauchinone, and then stimulated for $18 \mathrm{~h}$ with LPS. Culture supernatants of culture medium were collected and the concentration of TNF- $\alpha$ and IL- $1 \beta$ was determined using ELISA kits (R\&D Systems) as per manufacturer's instructions.

Western Blot Analysis RAW264.7 cells were harvested and pelleted at $200 \mathrm{~g}$ for $3 \mathrm{~min}$ later washed with phosphatebuffered saline (PBS) and lysed with $20 \mathrm{~mm}$ Tris- $\mathrm{HCl}$ buffer (pH 7.4) containing protease inhibitor mixture $(0.1 \mathrm{~mm}$ phenylmethanesulfonyl fluoride, $5 \mathrm{mg} / \mathrm{ml}$ aprotinin, $5 \mathrm{mg} / \mathrm{ml}$ pepstatin A, and $1 \mathrm{mg} / \mathrm{ml}$ chymostatin). Protein concentration was determined using the Lowry protein assay kit (P5626; Sigma). An equal amount of protein for each sample was resolved using 12\% sodium dodecyl sulfate-polyacrylamide gel electrophoresis (SDS-PAGE) and then electrophoretically transferred onto a Hybond enhanced chemiluminescence (ECL) nitrocellulose membrane (Bio-Rad, Heracules, CA, U.S.A.). The membrane was blocked with 5\% skimmed milk and sequentially incubated with primary antibody (Santa Cruz Biotechnology, CA, U.S.A.) and horseradish peroxidase-conjugated secondary antibody followed by ECL detection (Amersham Pharmacia Biotech, Piscataway, NJ, U.S.A.).

HO Activity The method used for the determination of HO activity follows the protocol published by Motterlini et $a .^{21)}$ Briefly, after the incubation process, the cells were washed twice with PBS, gently scraped off the dish, and centrifuged $\left(1000 \times \boldsymbol{g}\right.$ for $10 \mathrm{~min}$ at $\left.4{ }^{\circ} \mathrm{C}\right)$. The cell pellet was suspended in $\mathrm{MgCl}_{2}$ (2 mM) phosphate (100 mM) buffer ( $\mathrm{pH}$ 7.4), frozen at $-70^{\circ} \mathrm{C}$, thawed 3 times, and finally sonicated on ice before centrifugation at $18000 \times \boldsymbol{g}$ for $10 \mathrm{~min}$ at $4{ }^{\circ} \mathrm{C}$. The supernatant $(400 \mu \mathrm{l})$ was added to a reduced nicotinamide adenine dinucleotide phosphate (NADPH)-generating system containing $0.8 \mathrm{~mm}$ NADPH, $2 \mathrm{~mm}$ glucose-6-phos-
A

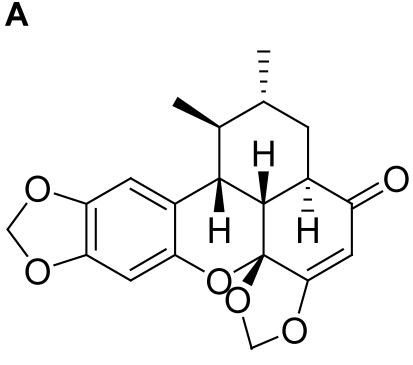

Sauchinone

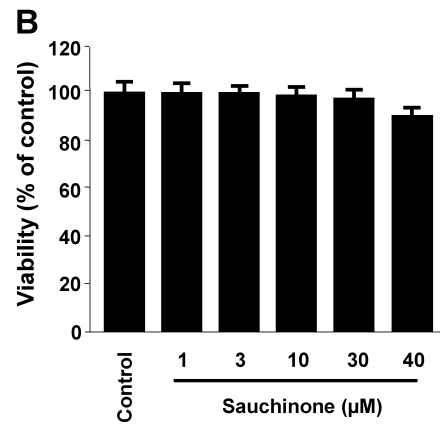

Fig. 1. Chemical Structure of Sauchinone and Effects of Sauchinone on Cell Viability

(B) RAW264.7 macrophages were incubated for $24 \mathrm{~h}$ with various concentrations of sauchinone $(1-40 \mu \mathrm{M})$. Cell viability was determined as described under Materials and Methods. Data represent the mean values of three experiments \pm S.D.

phate, 0.2 unit glucose-6-phosphate-L-dehydrogenase, and $2 \mathrm{mg}$ protein of rat liver cytosol prepared from the $15000 \times \mathbf{g}$ supernatant fraction as a source of biliverdin reductase, potassium phosphate buffer $(100 \mathrm{~mm}, \mathrm{pH} 7.4)$, and hemin $(10 \mu \mathrm{M})$ in a final volume of $200 \mu \mathrm{l}$. The reaction was conducted for $1 \mathrm{~h}$ at $37^{\circ} \mathrm{C}$ in the dark and terminated by the addition of $1 \mathrm{ml}$ chloroform. The extracted bilirubin was calculated by determining the difference in absorption between 464 and $530 \mathrm{~nm}$.

Statistical Analysis Data are expressed as mean \pm S.D. of at least three independent experiments. To compare three or more groups, one-way analysis of variance (ANOVA) followed by Newman-Keuls post hoc test was used. Statistical analysis was performed with GraphPad Prism software, version 3.03 (GraphPad Software Inc., San Diego, CA, U.S.A.).

\section{RESULTS}

To determine the cytotoxic potential of sauchinone (Fig. 1A), its effect on viability of murine RAW264.7 macrophages was evaluated. Concentration of $30 \mu \mathrm{M}$ revealed no cytotoxic effects in MTT assay. However, higher concentration showed reduced viability of the macrophages (Fig. 1B). At the non-cytotoxic concentrations $(1-30 \mu \mathrm{M})$, RAW264.7 macrophages were challenged with LPS $(1 \mu \mathrm{g} / \mathrm{ml})$ in the presence or absence of the sauchinone and the levels of COX-2 and iNOS expression were measured. Pretreatment of the macrophages with sauchinone for $12 \mathrm{~h}$ resulted in decreased COX-2 expression (Fig. 2A) and COX-2-derived $\mathrm{PGE}_{2}$ production (Fig. 2C). The $\mathrm{PGE}_{2}$ production was found to have decrease by $5.1 \pm 1.7,15.6 \pm 1.2,46.3 \pm 0.9$ and $73.4 \pm$ $1.1 \%$. Under the same conditions, sauchinone also suppressed iNOS expression (Fig. 2B) and was also found to reduce the iNOS-derived NO (Fig. 2D) production (8.0 \pm 1.6 , $29.1 \pm 1.2,58.2 \pm 0.8,88.7 \pm 0.7 \%$ ). In this study, aspirin ( $>98 \%$ pure) was used as a positive control.

Moreover, the effects of sauchinone on the LPS-induced TNF- $\alpha$ and IL- $1 \beta$ production was examined by enzyme immunoassay in which RAW264.7 macrophages were pre-incubated with sauchinone for $12 \mathrm{~h}$ followed by LPS stimulation. As shown in Fig. 3, sauchinone also decreased TNF- $\alpha$ $(17.3 \pm 1.5,34.3 \pm 1.2,58.0 \pm 1.0,89.3 \pm 0.6 \%)$ and IL- $\beta$ $(12.7 \pm 2.2,27.9 \pm 2.3,52.4 \pm 1.4,77.6 \pm 1.1 \%)$ production in a concentration-dependent manner. 
A

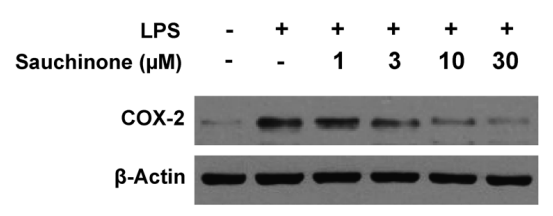

C

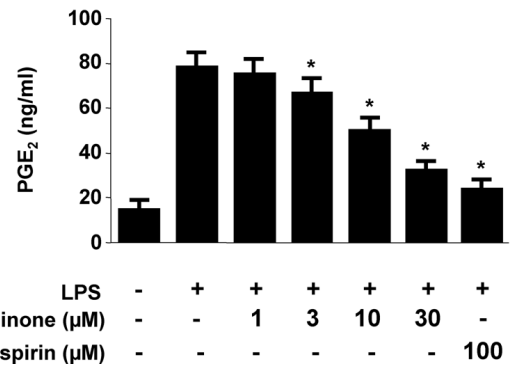

B

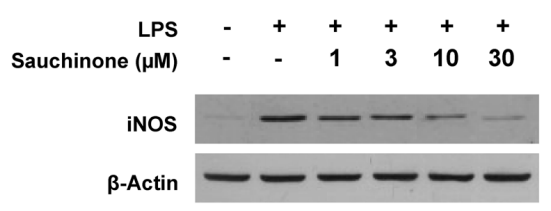

D

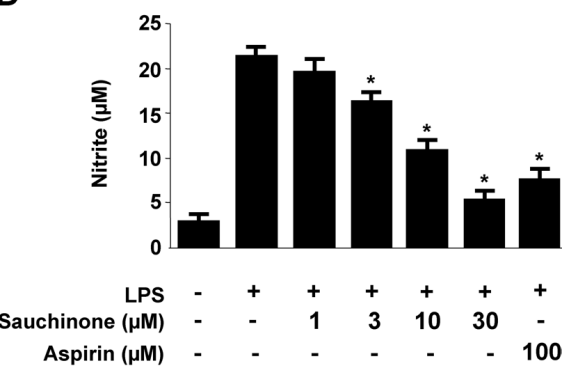

Fig. 2. Effects of Sauchinone on COX-2 and iNOS Expression and COX-2-Derived PGE 2 and iNOS-Derived NO Production in RAW264.7 Macrophages Stimulated with LPS

Cells were pre-treated for $12 \mathrm{~h}$ with indicated concentrations of sauchinone, and stimulated $6 \mathrm{~h}(\mathrm{~A}, \mathrm{C})$ or $18 \mathrm{~h}(\mathrm{~B}, \mathrm{D})$ with LPS $(1 \mu \mathrm{g} / \mathrm{ml})$. Western blot analyses for COX-2 (A) and iNOS expression (B) were performed as described in Materials and Methods and representative blots of three independent experiments are shown. The concentrations of PGE 2 (C) and NO (D) were determined as described under Materials and Methods. Aspirin $(100 \mu \mathrm{M})$ was used as a positive control. Data represent the mean values of three experiments \pm S.D. $* p<0.05 v s$. LPS.

At non-cytotoxic concentrations $(1-30 \mu \mathrm{M})$, sauchinone induced HO-1 expression in a concentration-dependent manner (Fig. 4A). In the macrophages treated with sauchinone $(30 \mu \mathrm{M}), \mathrm{HO}-1$ expression was first detected at $6 \mathrm{~h}$, maximum increase was observed around $18 \mathrm{~h}$, and reduced after $24 \mathrm{~h}$ (Fig. 4B). In accordance with the concentration-dependant HO-1 expression, sauchinone also increased HO activity (Fig. 4C). $\mathrm{HO}$ activity also showed maximal activity at $18 \mathrm{~h}$ after treatment (Fig. 4D).

As pre-incubation of the macrophages with sauchinone markedly inhibited LPS-induced pro-inflammatory enzymes and pro-inflammatory cytokines (Fig. 2) and since sauchinone was able to induce HO-1 expression (Fig. 4) in RAW264.7 macrophages, we examined whether sauchinonemediated HO-1 induction could be responsible for the inhibition of COX-2-derived PGE 2 , iNOS-derived NO, TNF- $\alpha$ and IL-1 $\beta$ production. RAW264.7 macrophages were pre-treated with sauchinone for $12 \mathrm{~h}$ in the presence of SnPP, a competitive inhibitor, followed by LPS stimulation. As shown in Fig. 5 , SnPP treatment partially reversed the inhibitory effects of sauchinone on $\mathrm{PGE}_{2}$, NO, TNF- $\alpha$ and IL- $1 \beta$ production.

We examined the effect of sauchinone on activation of MAPKs in RAW264.7 macrophages. At a concentration of $30 \mu \mathrm{M}$, which strongly induced the levels of HO-1, sauchinone activated the ERK pathway and increased ERK phosphorylation. As shown in Fig. 6A, phosphorylation of ERK was observed $15 \mathrm{~min}$ after sauchinone treatment, and was sustained up to $60 \mathrm{~min}$ after sauchinone treatment. In contrast, phosphorylation of JNK and p38 kinases was not seen at any time period. Furthermore, to investigate the role of MAPK in HO-1 expression, we examined the effects of specific inhibitors of ERK1/2 (PD98059), JNK (SP600125), and p38 (SB203580) on the levels of HO-1, by western blot. The ERK MAPK pathway inhibitor significantly reduced sauchinone-induced HO-1 expression, whereas the JNK and p38 inhibitors had no effect (Fig. 6B). The ERK inhibitor was not cytotoxic under our experimental conditions (data not shown).
A

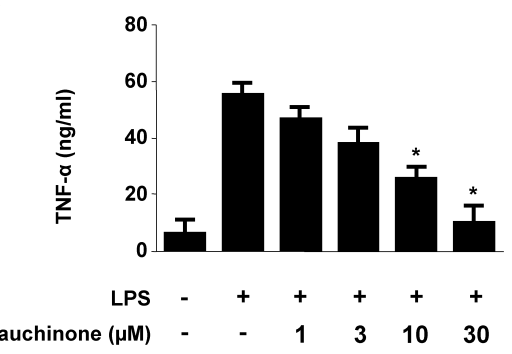

B

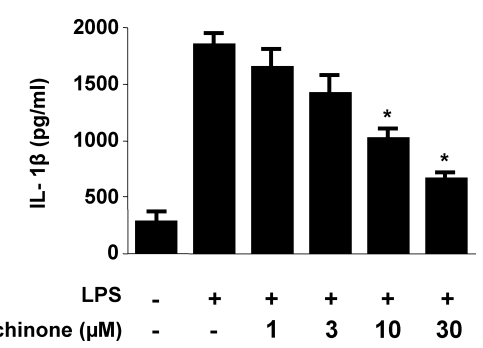

Fig. 3. Effects of Sauchinone on TNF- $\alpha$, and IL-1 $\beta$ Production in RAW264.7 Macrophages Stimulated with LPS

Cells were pre-treated for $12 \mathrm{~h}$ with indicated concentrations of sauchinone, and stimulated for $18 \mathrm{~h}$ with LPS $(1 \mu \mathrm{g} / \mathrm{ml})$. The concentrations of TNF- $\alpha$ (A) and IL- $1 \beta$ (B) were determined as described under Materials and Methods. Data represent mean values of three $* p<0.05 v s$. LPS.

\section{DISCUSSION}

Sauchinone is a unique and biologically active lignan found in Saururus chinensis, a perennial herbaceous plant with potential therapeutic utility in treatment of various diseases. The biological functions of sauchinone such as anti-inflammatory and immunosuppressive effects have been studied extensively. In previous studies, sauchinone is demonstrated to suppress the expression of pro-inflammatory mediators such as iNOS, COX-2 and tumor necrosis factor (TNF) 
A

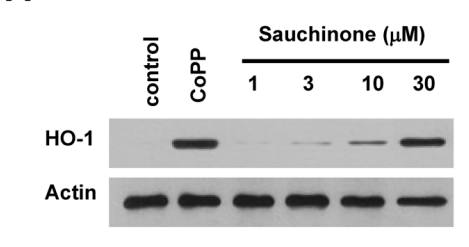

B

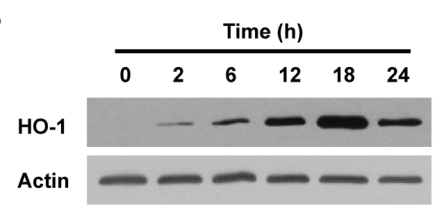

C

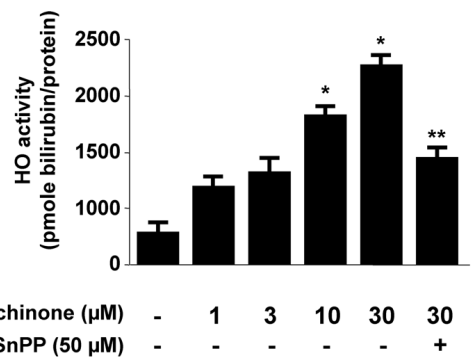

D

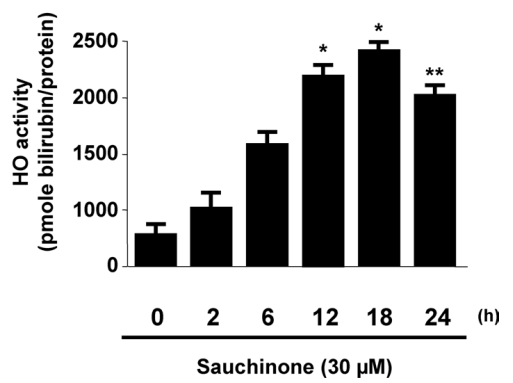

Fig. 4. Effects of Sauchinone on HO-1 Expression and HO Activity in RAW264.7 Macrophages

Cells were incubated for $12 \mathrm{~h}$ with indicated concentrations of sauchinone (A,C) and periods with $30 \mu \mathrm{m}$ of sauchinone (B). Western blot analysis for HO-1 expression (A, B) was performed as described in Materials and Methods and representative blots of three independent experiments are shown. HO activity $(C, D)$ was determined as described in Materials and Methods. Data represent the mean values of three experiments \pm S.D. $* p<0.05 v s$. untreated control; $* * p<0.05 v s$. sauchinone + LPS.

A

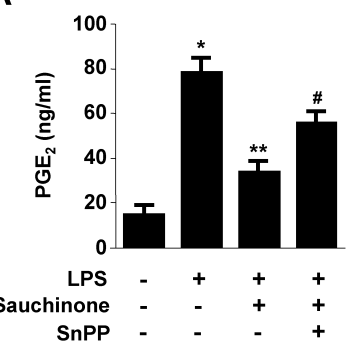

B

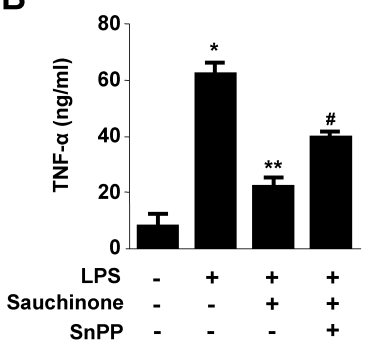

C

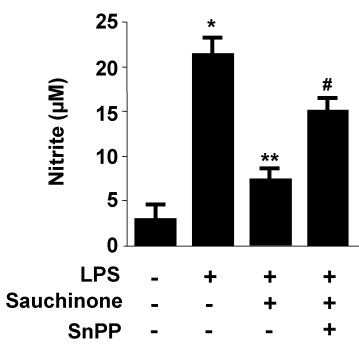

D

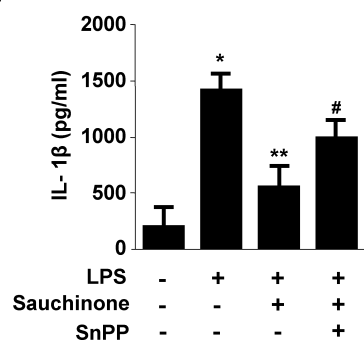

Fig. 5. Effects of SnPP on Inhibition of $\mathrm{PGE}_{2}, \mathrm{NO}, \mathrm{TNF}-\alpha$ and IL-1 $\beta$ Production by Sauchinone Pre-treatment of LPS-Stimulated Macrophages

Cells were pre-treated for $12 \mathrm{~h}$ with sauchinone $(30 \mu \mathrm{M})$ in the presence or absence of SnPP $(50 \mu \mathrm{M})$, and stimulated for $18 \mathrm{~h}$ with LPS ( $1 \mu \mathrm{g} / \mathrm{ml})$. The concentrations of PGE 2 , NO, TNF- $\alpha$ and IL- $\beta$ were determined as described in Materials and Methods. Data represent mean values of three experiments \pm S.D. $* p<0.05 v s$. untreated control; $* * p<0.05$ $v s$. LPS alone; $\# p<0.05 v s$. sauchinone+LPS.

through the inhibition of nuclear factor-kappa B (NF- $\kappa \mathrm{B})$ and AP1. ${ }^{12,17)}$ However, the underlying mechanisms that could substantially explain the anti-inflammatory effect of sauchinone still remain to be elucidated. In this study, we aimed to examine the potency of sauchinone as an anti-inflammatory HO-1 inducer and its regulation of RAW264.7 macrophages. We investigated the possible involvement of HO-1 in the anti-inflammatory activities contributed by sauchinone and also examined whether sauchinone-mediated HO-1 expression correlates with inhibition of LPS-induced pro-inflammatory mediators, such as $\mathrm{NO}, \mathrm{PGE}_{2}, \mathrm{TNF}-\alpha$ and

\section{IL-1 $\beta$.}

Inducible NOS (iNOS) is expressed predominantly in macrophages, that is implicated in organ destruction in some inflammatory and auto immune disorders. ${ }^{22)} \mathrm{COX}-2$ enzyme is another important mediator which is the predominant isoform of cyclooxygenase at the site of inflammation. COX-2derived $\mathrm{PGE}_{2}$ plays a regulatory role in a variety of physiological and pathological processes following an immune response and inflammation. ${ }^{23)}$ Pre-treatment with at $1-30 \mu \mathrm{m}$ sauchinone suppressed the expression of COX-2 and iNOS in LPS-stimulated macrophages, thereby inhibiting COX-2- 


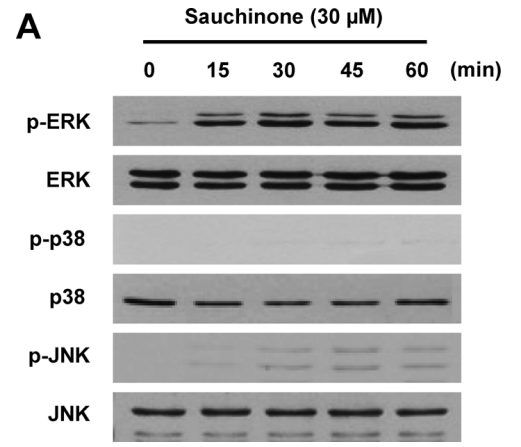

B

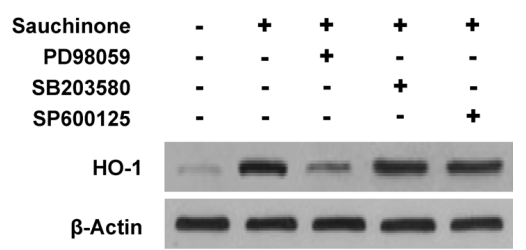

Fig. 6. Effects of Sauchinone on MAPK Activation and MAPK Dependent HO-1 Expression in Macrophage

(A) Cells were treated with $30 \mu \mathrm{m}$ sauchinone for the indicated times. Cell extracts were analyzed by Western blot with antibodies specific for phosphorylated ERK1/2 (p-ERK), phosphorylated JNK (p-JNK), or phosphorylated p38 (p-p38). Membranes were stripped and re-probed for total form of each MAPK antibody as a control, and the representative blots of three independent experiments are shown. (B) Cells were pretreated for $1 \mathrm{~h}$ with the specific inhibitor PD98059 (40 $\mu \mathrm{M})$, SP600125 (25 $\mu \mathrm{M})$ and SB203580 (20 $\mu \mathrm{M})$, and then treated with sauchinone $(30 \mu \mathrm{M})$ for $12 \mathrm{~h}$. Western blot analyses for HO-1 expression were performed as described in Materials and Methods and representative blots of three independent experiments are shown.

derived $\mathrm{PGE}_{2}$ as well as iNOS-derived NO production. In addition, sauchinone also inhibited LPS-induced TNF- $\alpha$ and IL- $1 \beta$ production. This finding suggests that sauchinone, at least in LPS-stimulated macrophages, exerts its antiinflammatory effects by limiting the expression of the proinflammatory enzymes and inhibiting the secretion of the pro-inflammatory cytokines.

In a previous study, it was demonstrated that the protective effects of sauchinone is primarily by up-regulating heme oxygenase-1 in HepG2 cells. $^{24)}$ In this study, we found that sauchinone not only induces the HO-1 expression and increases $\mathrm{HO}$ activity but it also does not affect cell viability at $1-30 \mu \mathrm{M}$ in RAW264.7 cells. The present study further examined whether sauchinone inhibited LPS-induced pro-inflammatory mediators, such as $\mathrm{COX}$-2-derived $\mathrm{PGE}_{2}$, iNOSderived NO, TNF- $\alpha$ and IL- $1 \beta$ by increasing expression of HO-1. Our results indicate that the inhibition of $\mathrm{HO}$ activity by the HO inhibitor SnPP had partially reversed the inhibitory effects of sauchinone on $\mathrm{PGE}_{2}, \mathrm{NO}, \mathrm{TNF}-\alpha$ and IL$1 \beta$ production in LPS-stimulated macrophages (Fig. 5). Inhibition of HO-1 activity by SnPP abolished these effects, indicating that HO-1 expression plays a vital role in the inhibition of LPS-induced inflammatory responses by sauchinone. Thus, we could infer that sauchinone-induced HO-1 expression may be a key mechanism for the anti-inflammatory property exhibited by this compound.

MAPKs are a group of serine/threonine protein kinases that are activated in response to diverse extracellular stimuli that mediate signal transduction from the cell surface to the nucleus. In mammalian cells, there are three well-define MAPK pathways: the extracellular signal-regulated kinase (ERK) pathway, the Jun N-terminal kinase (JNK) pathway and the p38 pathway. ${ }^{8}$ Previously, it has been observed that the MAPK pathways played a regulatory role in HO-1 gene expression. ${ }^{25,26)}$ In this study, activation of the ERK pathway appeared to be involved in sauchinone-induced HO-1 expression (Fig. 6) as specific protein kinase inhibitors of ERK pathway played key role in the induction of HO-1. Similar to the results of this study, activation of ERK was found to be required for the induction of HO-1 in several cells treated with diallyl sulfide, arsenite and brazilin. ${ }^{26-28)}$ In our previous study, we have demonstrated that HO-1 induction via ERK pathways appear to play key roles in the cyto-protection of HT22 cells. ${ }^{18)}$ This may be due to the diverse, assortment and intensity of the complex signaling pathways activated by different inducers in diverse cell types. Sauchinone-induced HO-1 expression is directly related to the ERK pathway as ERK inhibitor PD98059 influenced the sauchinone-induced change in the HO-1 protein level, while the inhibitors of JNK and $\mathrm{p} 38$ pathways did not display any significant influence.

The by-products of the heme oxygenase reaction, which include free ferrous iron, carbon monoxide, and biliverdin/ bilirubin, have also shown to exert a variety of biological activities. Carbon monoxide has been reported to suppress $\mathrm{PGE}_{2}, \mathrm{NO}, \mathrm{TNF}-\alpha$, and IL- $1 \beta$ production in LPS-stimulated macrophages through its interference of NF- $\kappa \mathrm{B}$ activation. ${ }^{2,6,7)}$ Studies have demonstrated that inflammatory stimuli induces the expression of HO-1 thereby suggesting that HO-1 expression is an adaptive cellular response to inflammation. ${ }^{29)}$ Since sauchinone, as confirmed in this study, can actively induce the expression of the anti-inflammatory HO-1 in macrophages, possibility cannot be ruled out that anti-inflammatory effects of sauchinone could be mediated, partially, by the products of $\mathrm{HO}-1$ enzyme reaction-namely, $\mathrm{CO}$, bilirubin and/or biliverdin.

In conclusion, this study has demonstrated that non-cytotoxic concentration $(1-30 \mu \mathrm{M})$ of sauchinone, actively induced HO-1 expression via ERK pathway in RAW264.7 macrophages leading to suppression of LPS-induced $\mathrm{PGE}_{2}$, NO, TNF- $\alpha$, and IL- $1 \beta$ production and mitigation of inflammatory process. This study strongly suggests that sauchinone may be a promising therapeutic agent for the treatment of inflammatory diseases.

Acknowledgements This research was supported by Basic Science Research Program through the National Research Foundation of Korea (NRF) funded by the Ministry of Education, Science and Technology (MEST) (No. 20100029467).

\section{REFERENCES}

1) Chung H. T., Pae H. O., Cha Y. N., Curr. Pharm. Des., 14, 422-428 (2008).

2) Abraham N. G., Kappas A., Pharmacol. Rev., 60, 79-127 (2008).

3) Ryter S. W., Alam J., Choi A. M., Physiol. Rev., 86, 583-650 (2006).

4) Otterbein L. E., Bach F. H., Alam J., Soares M., Tao Lu H., Wysk M., 
Davis R. J., Flavell R. A., Choi A. M., Nat. Med., 6, 422-428 (2000).

5) Wiesel P., Foster L. C., Pellacani A., Layne M. D., Hsieh C. M., Huggins G. S., Strauss P., Yet S. F., Perrella M. A., J. Biol. Chem., 275, 24840-24846 (2000).

6) Suh G. Y., Jin Y., Yi A. K., Wang X. M., Choi A. M., Am. J. Respir. Cell Mol. Biol., 35, 220-226 (2006).

7) Oh G. S., Pae H. O., Lee B. S., Kim B. N., Kim J. M., Kim H. R., Jeon S. B., Jeon W. K., Chae H. J., Chung H. T., Free Radic. Biol. Med., 41, 106-119 (2006).

8) Liu Y., Shepherd E. G., Nelin L. D., Nat. Rev. Immunol., 7, 202-212 (2007).

9) Iles K. E., Dickinson D. A., Wigley A. F., Welty N. E., Blank V., Forman H. J., Free Radic. Biol. Med., 39, 355-364 (2005).

10) Stanciu M., Wang Y., Kentor R., Burke N., Watkins S., Kress G., Reynolds I., Klann E., Angiolieri M. R., Johnson J. W., DeFranco D. B., J. Biol. Chem., 275, 12200-12206 (2000).

11) Chung B. S., Shin M. G., "Dictionary of Korean Folk Medicine," Young Lim Sa, Seoul, 1990, p. 813.

12) Lee A. K., Sung S. H., Kim Y. C., Kim S. G., Br. J. Pharmacol., 139, $11-20$ (2003).

13) Sung S. H., Kim Y. C., J. Nat. Prod., 63, 1019-1021 (2000).

14) Sung S. H., Lee E. J., Cho J. H., Kim H. S., Kim Y. C., Biol. Pharm. Bull., 23, 666-668 (2000).

15) Song H., Kim Y. C., Moon A., Biol. Pharm. Bull., 26, 1428-1430 (2003).

16) Park S. Y., Lee S. H., Choi W. H., Koh E. M., Seo J. H., Ryu S. Y., Kim
Y. S., Kwon D. Y., Koh W. S., Planta Med., 73, $674-678$ (2007).

17) Hwang B. Y., Lee J. H., Jung H. S., Kim K. S., Nam J. B., Hong Y. S., Paik S. G., Lee J. J., Planta Med., 69, 1096-1101 (2003).

18) Li B., Jeong G. S., Kang D. G., Lee H. S., Kim Y. C., Eur. J. Pharmacol., 614, 58-65 (2009).

19) Jeong G. S., An R. B., Pae H. O., Chung H. T., Yoon K. H., Kang D. G., Lee H. S., Kim Y. C., Planta Med., 74, 1368-1373 (2008)

20) Jeong G. S., Li B., Lee D. S., Kwon J. W., Lee H. S., Kwon T. O., Kim Y. C., Korean J. Pharmacogn., 38, 176-180 (2007).

21) Motterlini R., Foresti R., Intaglietta M., Winslow R. M., Am. J. Physiol., 270, H107-H114 (1996).

22) Kleinert H., Pautz A., Linker K., Schwarz P. M., Eur. J. Pharmacol., 500, 255-266 (2004).

23) Griswold D. E., Adams J. L., Med. Res. Rev., 16, 181-206 (1996).

24) Jeong G. S., Lee D. S., Li B., Byun E., Kwon D. Y., Park H., Kim Y. C., Planta Med., 76, 41-47 (2010).

25) Kietzmann T., Samoylenko A., Immenschuh S., J. Biol. Chem., 278, 17927-17936 (2003).

26) Elbirt K. K., Whitmarsh A. J., Davis R. J., Bonkovsky H. L., J. Biol. Chem., 273, 8922-8931 (1998).

27) Gong P., Hu B., Cederbaum A. I., Arch. Biochem. Biophys., 432, 252 260 (2004).

28) Choi B. M., Kim B. R., Eur. J. Pharmacol., 580, 12-18 (2008).

29) Rushworth S. A., Chen X. L., Mackman N., Ogborne R. M., O'Connell M. A., J. Immunol., 175, 4408-4415 (2005). 